\title{
Analysis of the use of Twitter as a tool for the management and communication of the CSR of leading European firms
}

\author{
Patricia Rodríguez and Ricardo Chalmeta* \\ Grupo de Integración y Re-Ingeniería de Sistemas (IRIS), \\ Dept. Lenguajes y Sistemas informáticos, \\ Universitat Jaume I, \\ Av. Sos Baynat s/n. 12560, Castellón de la Plana, Castellón, Spain \\ Email: patricia.rgz@gmail.com \\ Email: rchalmet@uji.es \\ *Corresponding author
}

\begin{abstract}
The management of corporate social responsibility (CSR) requires dialogue between the organisation and its stakeholders. Considering that, today, interaction among any members of society is becoming increasingly faster and easier due to the use of Web 2.0, this latter can be considered a suitable tool for CSR management. The main purpose of this paper is to analyse the use of online social networks by enterprises as a communication strategy tool in the field of CSR management. To this end, all the messages from the verified Twitter accounts of 50 leading European blue-chip companies (EuroStock 50) from the year they were activated until June $2016(127,811)$ were analysed using automated and manual content analysis. The conclusions drawn by this study show that this social network is only used for informative purposes, no two-way collaborative communication strategy being found. This leads to the need to proactively make companies aware of the advantages of social networks as CSR management tools and drivers of a collaborative interaction with stakeholders that would allow a more sustainable and more inclusive performance of CSR principles in their activities.
\end{abstract}

Keywords: corporate social responsibility; CSR; Twitter, stakeholders; communication strategy; Web 2.0.

Reference to this paper should be made as follows: Rodríguez, P. and Chalmeta, R. (xxxx) 'Analysis of the use of Twitter as a tool for the management and communication of the CSR of leading European firms', Int. J. Web Based Communities, Vol. X, No. Y, pp.xxx-xxx.

Biographical notes: Ricardo Chalmeta is an Associate Professor in Computer Science and the Director of the Systems Integration and Re-Engineering Research Group (IRIS) at the Universitat Jaume I of Castellón, Spain. He has worked as the Director in Spanish and European R\&D projects. He has been invited as both a researcher and a Lecturer by different universities. He has served as a consultant in several transport and manufacturing firms. He has published research papers in a number of leading journals and in several international conferences. He has been member of the scientific committee of several international conferences and chairman of several sessions.

Patricia Rodríguez González is a Market Analyst, Business Developer and SEO Specialist at Banabio, S.A., a leading exporter of organic bananas in Ecuador. She has also worked as an environmental, quality, health and safety technical 
expert at Sertego, S.L.U., a company of the industrial sector for the sustainable management of hazardous and non-hazardous industrial waste, and at Vodafone, where her work was focused on the statistical analysis of data, oriented to obtain a global customer satisfaction indicator. She has a degree in Environmental Sciences (Universidad Autonoma de Madrid, 2005), Spain, and a Master degree in Sustainability and CSR (UNED, 2016).

\section{Introduction}

The vision that established that the main objective of a company is to obtain an exclusively economic benefit has changed, since it is known that the impacts of an organisation go beyond the economic ones. This has led to the emergence of corporate social responsibility (CSR), which can be defined as "the voluntary integration of social and environmental concerns in the enterprises' daily business operations and in the interaction with their stakeholders. In a broader sense it is defined as a concept whereby companies decide voluntarily to contribute to a better society and a cleaner environment" (Commission of the European Communities, 2001).

Currently, CSR is a differentiating factor for companies and a tool for competitiveness (Ruf et al., 2001). Thus, a good reputation in CSR issues improves the company's performance, which in turn leads to increased sales and productivity due to a higher degree of customer and employee loyalty (Maignan, 2001), and as a result the company image is also enhanced (Smith, 2003).

CSR requires a new model of interaction between the company and its stakeholders. Stakeholders were defined by Freeman (1984) as "any group or individual that can affect or be affected by the realisation of an organisation's purpose". Stakeholder theory argues that, beside shareholders, there are other parties whose interests should be involved in enterprise decision-making, including communities, associated corporations, prospective employees, governmental bodies, political groups, trade associations and the public at large (Kakabadse et al., 2005). However, the incorporation of CSR is often more superficial than effective. One of the main causes of this lack of integration is that companies do not know how to address CSR in a holistic way by including all the aspects involved in CSR that concern their stakeholders (Figge et al., 2001).

To solve this problem, communication with stakeholders is a key factor. Communication with company stakeholders promotes the materialisation of sustainability values in real actions that align stakeholders' expectations with company performance.

Therefore, the CSR communication strategy adopted by the company should be led by the demands of the company stakeholders, allowing a bidirectional interaction between the company and the stakeholders, and achieving their real involvement in CSR decision-making at all levels (Morsing and Schultz, 2006). To do so, a communication channel must be used that does not allow it to be monopolised by the company. In addition, such a channel must be agile in the response to the demands of the stakeholders, since not disappointing their expectations is a key factor (Weiner, 2006). Of such importance is speed in the interaction with stakeholders that the decrease in the corporate reputation may be bigger in a scenario of a minor crisis, where the company remains silent or appears missing, than in a scenario of a big crisis, where the communication reaction of the company is very rapid (Baccarella et al., 2018; Weiner, 2006). Therefore, 
it is crucial that company CSR communication uses fast media for its development (Cunningham et al., 2015).

In this context, the online social networks are a good solution to CSR communication (Cortado and Chalmeta, 2016). Online social networks favour participation and offer a communicative structure based on dialogue and interaction among equals (Fredericks and Foth, 2013). They allow:

1 interaction and collaboration among all the stakeholders of an organisation in real time and in a simple and immediate way

2 the different interests of each stakeholder to be identified, thereby promoting the generation of new knowledge and developing collective intelligence (Kolbitsch and Maurer, 2006)

3 information to be obtained regarding the performance of the enterprise in all areas, thus guaranteeing the transparency and speed required in this communication.

In addition, another reason for the use of social networks as a means of CSR communication is the growing demographic variety that uses social networks and smartphones as primary sources of communication in society (Fredericks and Foth, 2013).

In this scenario, an adequate communication strategy in social networks is fundamental for the real integration of CSR. This communication strategy should guarantee symmetry between the company and its stakeholders, allowing the participation of the latter in the management of different aspects of CSR. However, numerous past studies have revealed that companies had little interest in interacting with stakeholders in CSR issues (Angeles and Capriotti, 2009) and the few studies that have been conducted on CSR communication through online social networks showed that companies used online social networks mainly for the dissemination of information, without establishing a dialogue with their stakeholders (Cortado and Chalmeta, 2016).

Therefore, there is room for new studies that:

1 analyse whether companies are making proper use of online social networks as a two-way CSR communication tool with an interactive approach to the relationship with their stakeholders, that is, "a two-way communication between source and receiver" (McMillan, 2006)

2 analyse a new cultural environment considering companies in other countries, such as European countries, on which no study of this type has been carried out, or

3 perform longitudinal analyses to study the trend.

To help solve this problem, this paper analyses the CSR publications posted on the official Twitter profiles of the most important European companies (the organisations listed on the Euro Stoxx 50 index), from their year of activation until June 2016, in order to answer the following research questions:

1 Is the social network Twitter used to communicate aspects related to CSR (RQ1)?

2 Which topic of CSR is posted the most on Twitter (RQ2)?

3 What type of communication strategy is adopted (RQ3)? 
4 Does the company take the users' comments on Twitter into account in their CSR actions (RQ4)?

5 Is the content of the post aimed at all stakeholders in general or only one group (RQ5)?

6 Are companies using twitter for self-promoting or for stakeholders engagement (RQ6)?

This paper is structured as follows. Section 2 reviews the literature related to CSR communication through online social networks. Section 3 shows the research methodology. A description of the research findings is given in Section 4. Section 5 presents the discussion of the findings. Finally, Section 6 contains the conclusions from the study.

\section{Literature review}

\subsection{CSR and stakeholders theory}

CSR is focused on the way in which corporations manage

1 their economic, social and environmental impacts (the triple bottom line)

2 their relationships and negotiations with different groups of stakeholders and society in general (Ihlen et al., 2011).

Therefore, CSR is replacing in the organisations the shareholder model that defines company's main objective as safeguarding investors' interests by increasing profits (Friedman, 1970) by the stakeholder theory (Freeman, 1984), which sees a number of other groups (called stakeholders) as being valuable to the company, and consequently their interests must be also deemed worthy of attention and consideration. Examples of a company's stakeholders are employees, executives, shareholders, investors, final consumers, citizens, suppliers, financial institutions, trade unions, government, local communities, media, competitors, academics, associations and NGOs.

According to the stakeholder theory, the company has to be managed in such a way as to create value for all stakeholders not only to produce financial gains, because their good performance depends on the degree of alignment with the expectations of their stakeholders (Freeman et al., 2010). Therefore, the enterprise needs to identify and to understand the stakeholders' requirements. Only by satisfying these stakeholders' requirements can the organisation survive and succeed (Yin et al., 2015).

\subsection{CSR Communication}

Commitment with stakeholders and CSR communication and reporting are key strategies that must be used to incorporate CSR within an organisation (Visser and Tolhurst, 2010). CSR commitments and actions of the enterprise cannot remain internalised within the company. If a company is involved in CSR activities, it will be interested in making this fact public to their stakeholders (Vollero et al., 2016). 
According to Morsing and Schultz (2006), two CSR communication strategies can be distinguished, depending on the type of relationship that an organisation establishes with its stakeholders:

- One-way communication, which can be classified in to types:

1 Stakeholder information strategy, the goal of which is to disseminate information. Some examples are articles produced by companies for journals, web, magazines, etc. This strategy does not consider that CSR initiatives of the company must be approved or promoted by the stakeholder, which would be a guarantee of transparency and credibility.

2 Stakeholder response strategy. In this strategy there is no open dialogue and although the response of the stakeholders is allowed, the company's replies are redirected towards their own interests in pursuit of an economic benefit (sometimes it is considered as a type of bidirectional strategy but it is asymmetric in nature). In both types of one-way communication, companies' main objective is to obtain profit of the advantages that a good CSR reputation offers more than to get stakeholders' engagement. Companies know that there is a rise in stakeholders' interest in receiving information of enterprises with a good social and environmental reputation (Chalmeta and Viinikka, 2017), and this interest can have a positive impact on their competitive advantages (Uzunoğlu et al., 2017). For example, customers pay more for products and services of companies with good CSR reputation (Baksh-Mohammed et al., 2012).

- Two-way communication, also called stakeholder involvement strategy. In this case, both parts involved in the dialogue are willing to change/improve (symmetrical bidirectional strategy). In this type of strategy, the company must be able to establish a constant, sustained, continuous and systematic interaction with the different stakeholders.

Among the different types of communication between the company and their stakeholders, only the two-way communication offers a solid and bidirectional communication that guarantees the interaction with the company's stakeholders and allows the company to know the stakeholders' necessities and the subsequent development of the actions that are needed to fulfil them. The bi-directionality feature is fundamental in a CSR communication strategy and it should be always adopted by companies if they want to a true integration of CSR principles into the values of the organisation.

\subsection{Online CSR communication}

Enterprise CSR can be communicated to the stakeholders via different methods: annual CSR and sustainability reports, print media and TV channels, or the internet using the enterprise website or online social media. However, in a recent study by the European Commission (2013), 62\% of Europeans said they did not feel informed about enterprises' responsible behaviour. Different studies have been conducted to analyse whether the problem is that companies are not communicating CSR at all or if they are simply not communicating CSR activities effectively (Chaudhri and Wang, 2007; Gomez and 
Chalmeta, 2011; Etter, 2013, 2014; Farache et al., 2018; Ettinger et al., 2018). Results show that

1 companies continue to display a low level of communication regarding CSR matters

2 their communication is mainly one-way with their stakeholders, who may or may not have been willing participants in the communication process

3 enterprises have little interest in interacting with stakeholders on CSR issues

4 the internet is the best medium for CSR communication to the enterprise's various stakeholders

5 websites are the best media for one-way CSR communication but they offer limited possibilities for two-way CSR communication.

In this context, social networks appear as the ideal channels of communication to reach a better two-way CSR communication with the groups of interest for the following reasons (Lovejoy and Saxton, 2012; Cortado and Chalmeta, 2016; Morsing and Schultz, 2006):

1 They allow the active participation of the stakeholders.

2 Their content is not defined by just one of the actors, but is constructed by both the company and the stakeholders.

3 They are a route of rapid consultation about doubts regarding the CSR reports posted by the company.

4 They enable immediate, permanent and visible feedback with the stakeholders so as to know what is relevant. Therefore, they allow for better alignment between the company's strategy and the needs of its stakeholders.

5 They offer a greater capability to disseminate information more quickly and effectively than the traditional means.

6 There are increasingly more users who use online social networks to formulate opinions about companies.

7 They offer greater transparency in crisis management, as well as the capacity to react rapidly so as to minimise the consequences.

8 They appear as a two-way communication tool that is not controlled unilaterally by the organisation and this allows better adjustment to the stakeholders' expectations. The company does not select the information to be posted but does so in answer to the demands. The simple posting of CSR information can give stakeholders the perception that the company is producing propaganda-style material and this may damage the company's image.

9 They allow for greater flexibility in the adjustments to different scenarios, taking into account that CSR objectives can change.

Nevertheless, while different empirical studies demonstrate the importance of the twoway communication strategy for the correct incorporation of CSR in the company, other studies point out that this communication strategy has still not been adopted in the online social networks. The following conclusions can be extracted from these studies: 
1 over the last years there has been an important increase in the importance of online social media in CSR communication (Whelan et al., 2013; Szumniak-Samolej, 2019), especially for promoting, hiring, reporting, and announcing (Chae and Park, 2018), although the level of CSR disclosure by the companies depend on the company sector (Suárez-Rico et al., 2018).

2 In general, companies are not taking advantage of the opportunities offered by the social networks for CSR communication and to establish an interactive dialogue with their stakeholders (Gómez, 2013; Waters and Williams, 2011; Colleoni, 2013).

3 Social networks management should play an important role in the CSR strategy, as a way to adopt a symmetrical two-way communication approach, which happens when companies allow stakeholders and/or other actors to post comments on enterprise CSR publications and the enterprise answers these publications (Cortado and Chalmeta, 2016).

4 The number of studies on the interactive features of CSR is still insufficient and are basically limited to three quantitative studies on Twitter (Etter, 2013, 2014; Farache et al., 2018), a qualitative study on social media in general (Illia et al., 2015), the online questionnaire carried out by Kollat and Farache (2017), and the content analysis of 1.383 customer online reviews of 47 hotels on TripAdvisor carry out by Ettinger et al. (2018).

5 Twitter can be used as a tool that favours the commitment of organisations with their stakeholders, as long as the companies make proactive use of it and they do not employ it as platform for the diffusion of irrelevant information or as a customer service (Lovejoy et al., 2012).

6 Although organisational profiles that tweet more often about CSR are more likely to generate engagement among Twitter users (Araujo and Kollat, 2018), not all the CSR related messages on Twitter have the same impact on stakeholders attitudinal and behavioural outcomes (Uzunoğlu et al., 2017).

7 Using stakeholder insights from twitter can aid companies in making strategic CSR decisions (Farache et al., 2018).

\section{Methodology}

The aim of this paper is to provide new knowledge about the use of online social networks for CSR management. To this end, data relating to CSR publications posted by the most important companies in Europe (the organisations listed on the Euro Stoxx 50 stock exchange index) have been collected from their official Twitter profiles and then classified and interpreted. This index was selected because it includes a group of organisations that are the leading reference for the rest of the members of each of their business sectors, in addition to the fact that they have not been considered in previous studies.

An analysis was performed of the tweets posted by this select group of companies in their official CSR accounts over the period from their year of activation to June 2016 $(127,811)$. After confirming that it was totally unfeasible to carry out a detailed reading 
of all the tweets posted by the companies, for later classification according to CSR criteria (within a reasonable period of time and in an objective manner), a script was designed using Python to carry out an automated content analysis. This script made it possible to download into an SQLite relational database all the tweets that contained one or more of the following CSR words: strategy, mission, vision, values, corporate, environmental, approach, labour, human, society, stakeholder, product, compliance, supply, impact, assessment, governance, economic, community, social, performance, practices, rights, responsibility, and chain. These words were selected after the analysis of the CSR topics of the first world standard for sustainability reporting (Global Reporting Initiative, GRI), and other complementary CSR topics proposed by Casadesús et al. (2005) and Escrig Tena (2015). After a manual content analysis, the tweets that were not related to aspects of CSR (sometimes although the tweet included "CSR words" the content had no CSR relation) were ruled out. Finally, a database was obtained contained a total of 3,010 CSR tweets. The language selected was English in order to guarantee a wider range of reach to all stakeholders of different nationalities. Appendix 1 shows the total tweets per company and year, and the total CSR tweets per company and year.

The tweets obtained through the script were manually coded according to the following criteria (their relation to the research questions shown in Section 1 of this paper is given in brackets) and descriptive statistics was used to analyse and show the data:

- The topic of CSR that the tweet mentions (RQ2). The messages were classified in topics, according to the CSR word that it contained. In those cases where a tweet could refer to more than one topic (the tweet contained two or more words with the name of different CSR topics), it was classified according to the topic considered to have the greatest impact due to the type of activity developed. However, there were some tweets that had similar environmental and social impact. For these tweets, a new CSR topic called "environment and society" was created. Appendix 2 shows an example of the CSR tweets of a company and how they were classified in topics and interest groups.

- Type of communication strategy adopted (RQ3): One-way informative, ONE-way responsive and two-way collaborative. To this end, the content of the tweets and retweets posted by the company was analysed to see if there was a predisposition, on the part of the company, to interact with its stakeholders in a collaborative manner. The content of the sustainability reports of the selected companies was also checked to see whether the contributions made by stakeholders on the online social network have had an impact on the attitude adopted by the company (RQ4). A sustainability report is a report by the company that gives information about its economic, environmental, social and governance performance (GRI, 2019).

- Interest group (stakeholder) to which the tweet is addressed (RQ5). The content of all the CSR tweets of all the companies was analysed in order to identify the interest group (stakeholder) to which the tweet was addressed. In cases where a tweet could be considered as targeting more than one interest group, it was coded as 'Miscellaneous'.

- Are companies using twitter for self-promoting or for stakeholders engagement? (RQ6). The content of each company's tweets was analysed in order to draw conclusions about whether the information posted by the companies allows them to know and evaluate their economic, social and environmental performance or, on the 
contrary, to see if the social network is only used to post content that strengthens their corporate image.

A coder (one of the authors of this paper) was trained to analyse all the tweets according to the above criteria. The other author of the paper was randomly assigned $10 \%$ of the sample. The measurement coefficient used to calculate intercoder reliability was percent agreement. The results of the intercoder reliability were from $92 \%$ till $99 \%$ depending on the category. The authors cross-validated each subjective assessment and solved all discrepancies until complete agreement was reached.

Furthermore, the year of activation of each company's Twitter account was also recorded, which gives an idea of the greater (or lesser) interest of each company in social networks (see Appendix 2), as well as their evolution in terms of their knowledge of the communication strategy adopted in CSR. The social network chosen was Twitter because of the high number of active users (310 million active users per month as of March 2016) and because it receives 1 billion unique monthly visits to websites with embedded tweets (Twitter, 2016). It has been possible to speed up the analysis of the content posted on this social network, thanks to the free availability of the SQLite relational database and the programming language Python. To find out whether the companies analysed had a Twitter profile, the official website of each company was searched. If they were not found, then the Twitter search engine itself was used to locate the official profiles and discard the others.

\section{Findings}

After applying the methodology detailed in Section 3, a total of 3,010 tweets related to CSR management, posted by the sample of 2016 Euro Stoxx 50 companies with an official Twitter account, were obtained. After studying the content of the publications, the results obtained are as follows:

\subsection{Use of Twitter to communicate CSR issues (RQ1)}

Figure 1 shows that in the space of six years, the percentage of Euro Stoxx 50 companies with an official Twitter account increased from $34 \%$ to $96 \%$. Therefore, of all the companies that make up the Euro Stoxx 50, 48 currently have an official account on Twitter.

Similarly, Figure 2 shows that the number of publications related to CSR in this period of time grew exponentially. In 2009, only 2 of the 17 companies with official accounts $(12 \%)$ posted CSR tweets. This scenario changed drastically when, in 2016, $96 \%$ of the sample studied had official accounts on Twitter with $88 \%$ of them posting tweets that mention aspects of CSR. Therefore, for RQ1 it can be concluded that companies do in fact use the Twitter social network to communicate CSR issues. 
Figure 1 Percentage of Euro Stoxx 50 companies with an official Twitter account in 2016 (see online version for colours)

\% Percentage of Euro Stoxx 50 companies with an official Twitter account

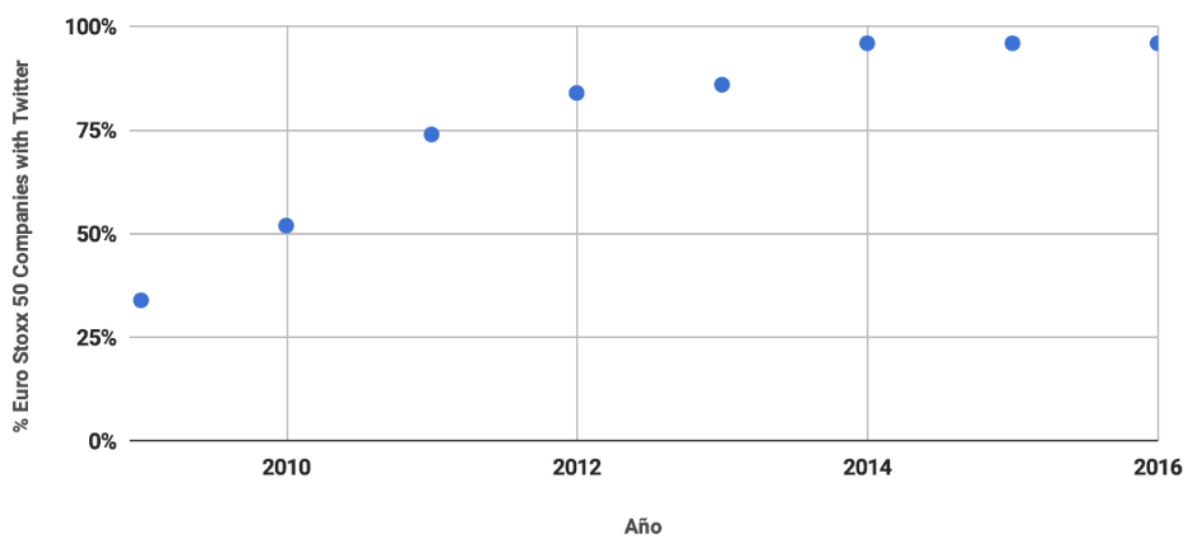

Figure 2 Percentage of Euro Stoxx 50 companies that have posted tweets with CSR content (see online version for colours)

\% Euro Stoxx 50 Companies that have published tweets with CSR content

$100 \%$

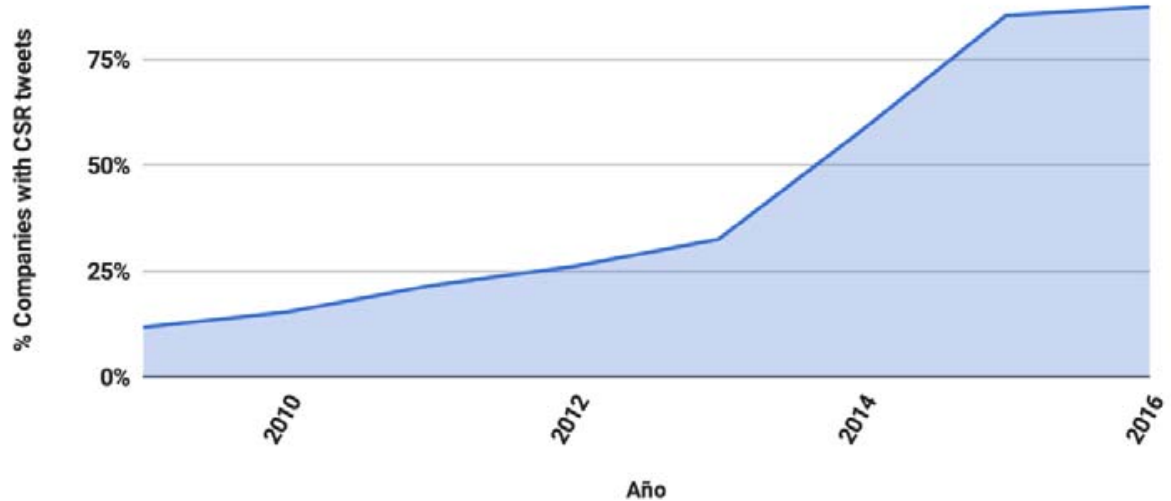

\subsection{Topic of CSR most frequently posted on Twitter (RQ2)}

In terms of which topic of CSR is the most posted on Twitter, the results obtained are shown in Figure 3. Not all the CSR topics initially considered had tweets. For RQ2, the topic of environmental impact stands out from the rest of the issues. 
Figure 3 Number of tweets posted by CSR topic (see online version for colours)

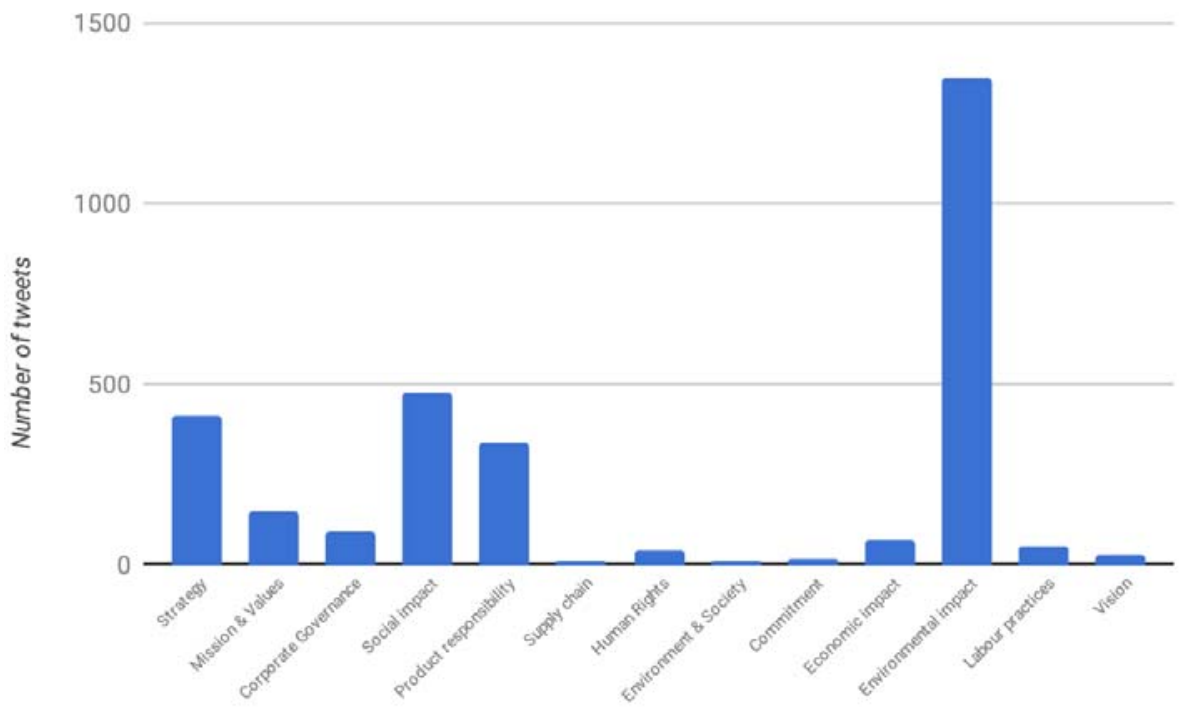

\subsection{Type of communication strategy adopted (RQ3)}

For RQ3, which asks the following question: "What kind of communication strategy is adopted?", the following result was obtained: $61 \%$ one-way information strategy and $39 \%$ one-way response strategy. In $0 \%$ of cases has a tweet been found that displays a two-way collaborative strategy.

The number of retweets made by companies to CSR-related issues (675) is five times lower than the number of CSR tweets posted in the same period $(3,010)$. On the other hand, in the analysis of their content, it has been observed that the majority of company retweets are made to Twitter profiles that are unrelated to the company (Figure 4). However, no retweeting to demands or needs expressed by any interest group is made by the company. The analysis of the content of these company retweets reveals that, in most cases, publications are made regarding the circulation of events or information regarding the advertising of the company's activity.

\subsection{Impact of Twitter communication on corporate CSR (RQ4)}

With regard to RQ4, in order to know whether the interaction of companies on CSR issues through Twitter reflects the decision-making process of the companies and is reflected in their sustainability reports, the data collected show that none of the reports available mention any comments collected through this social network and, in most cases, do not even refer to their existence (Figure 5). 
Figure 4 Comparison between the number of CSR retweets made on the organisation's profiles and on external profiles since the year their Twitter accounts were activated (see online version for colours)

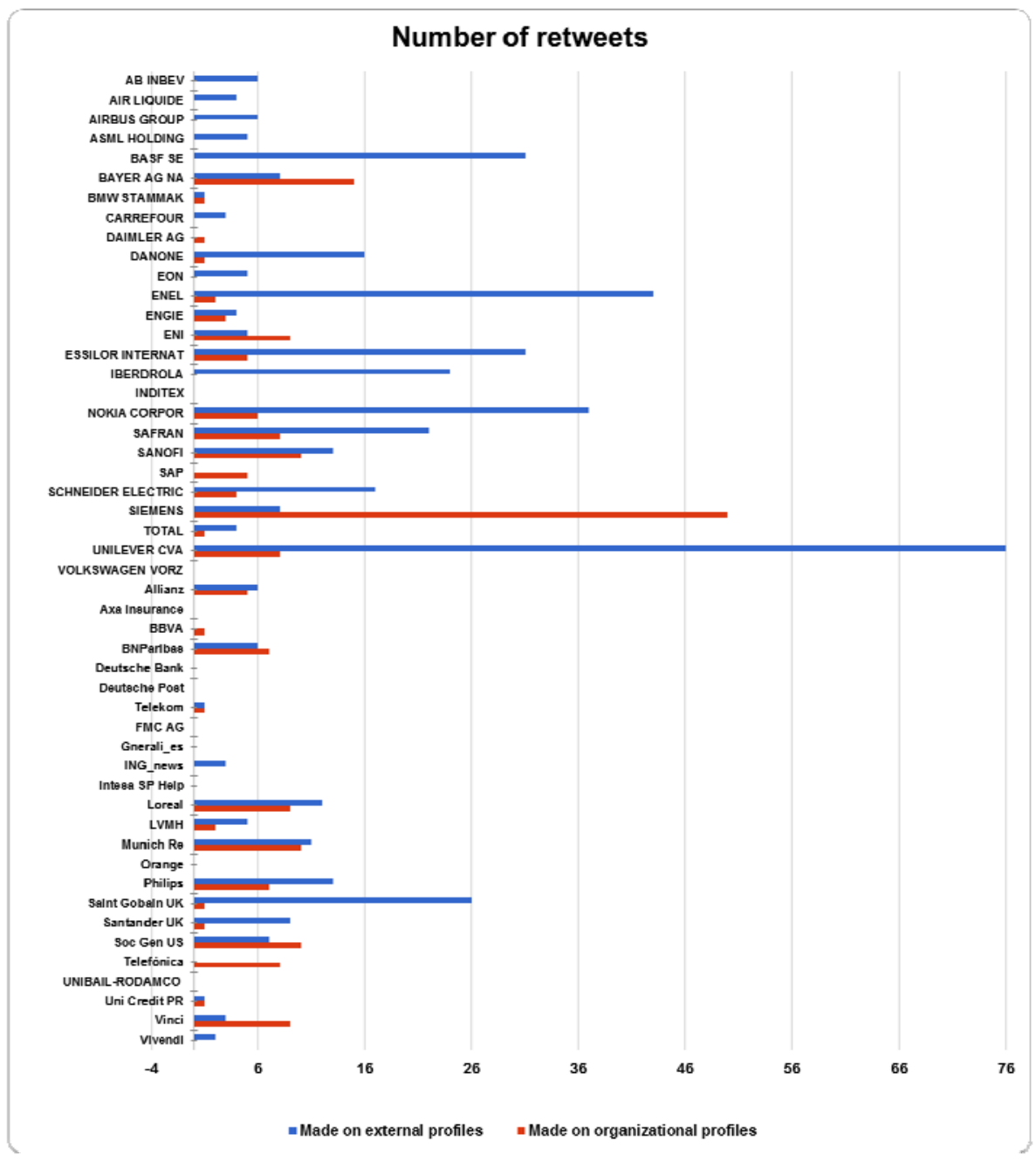


Figure 5 Mentions of official Twitter account in sustainability reports (see online version for colours)

Official Twitter account mentions on Sustainability Reports

Yes

No

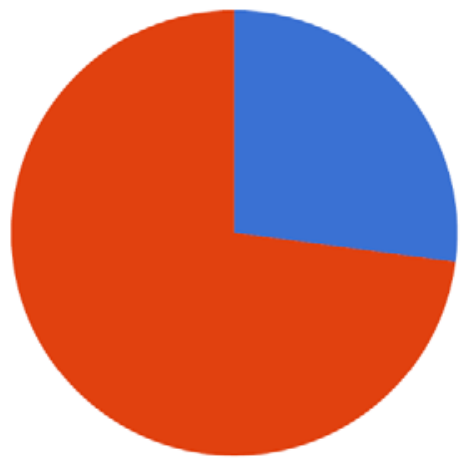

\subsection{Analysis of the users that companies communicate with (RQ5)}

The analysis of the companies' tweets showed that the tweets were addressed to the following stakeholders: shareholders, employees, customers, suppliers, society, environment and public bodies.

Table 1 shows that two groups, society and customers, represent $63.2 \%$ of the total publications. Conversely, Environment and 'miscellaneous' each obtain percentages higher than $10 \%$, while the rest of the groups only represent $13 \%$ of tweets, of which the Shareholders group stands out with $8.7 \%$ of that total. It is worth highlighting that Suppliers are very rarely mentioned (only one tweet in the entire sample analysed was directed towards them).

Table 1 Percentage of tweets targeted at each stakeholder

\begin{tabular}{lc}
\hline Stakeholder & Percentage of tweets \\
\hline Society & 36.7 \\
Customers & 26.5 \\
Shareholders & 8.7 \\
Employees & 3.2 \\
Environment & 12.8 \\
Public bodies & 1.16 \\
Suppliers & 0.04 \\
'Miscellaneous' & 10.9 \\
\hline
\end{tabular}

\subsection{Are companies using Twitter for self-promoting or for stakeholders engagement? (RQ6)}

In order to respond to RQ6 "Are companies using twitter for self-promoting or for stakeholders engagement?", the following are the observations on the tweets posted by 
each of the organisations studied, as well as a comparison between the number of tweets and retweets posted.

Most tweets refer to generic objectives in matters related to the environment and social impact. However, they do not allow any conclusions to be drawn about company improvements or projects related to the environment and social impact issues or their implementation over time. The largest percentage of Twitter posts are aimed at publicising the company. In most cases, they also contain generic messages (posted by the company itself) that only include positive messages regarding its environmental and social values.

\section{Discussion}

Through the use of social networks as CSR communication tools, greater transparency about the real performance of organisations can be achieved. However, this paper has shown that currently not all aspects of CSR are reported fairly. The environment is the topic that is mentioned the most, and there always seem to be positive aspects highlighted that aim to improve the corporate image. The instrumental use of CSR is already evident in some studies, such as the one carried out by Truño and Rialp in 2008, where the three companies analysed have the notion that CSR, as a system, can be used to improve their reputation.

The creation of value for all stakeholders must be the goal for all business management, according to stakeholder theory. However, the analysis of the recipients of CSR tweets posted by the companies studied reveals unequal treatment of the stakeholders. There is a high bias towards society and customers. This could show that the main goal of the post is to advertise products or services, or even the altruistic actions carried out by the foundations of each organisation. To avoid this situation, the capacities offered by Web 2.0 for dialogue between stakeholders and companies must be vindicated. This environment represents the best platform to guarantee that the company takes stakeholders' expectations into consideration, by allowing the dialogue not to be monopolised by the issues that offer greater competitive advantage to organisations. This climate of dialogue is reinforced by studies that analyse the opportunities offered by Web 2.0 as a tool for participation (Fredericks, 2013) and that highlight its potential for the development of local policies with the greatest involvement of its constituents.

To achieve this objective, which consists in using the online social network as a communication tool to reveal the expectations of a company's stakeholders, a real interest from the company's community managers is expected. However this does not seem to be the case judging by the results obtained in this work, as well as in other studies. One can conclude that, although social media provide organisations with interactive resources, they are not being used for such a purpose (Gómez, 2013). It can be confirmed that although, as mentioned above, the posting of tweets related to CSR management has increased in recent years, their content is far from a collaborative, twoway communication strategy. The content posted is not related to the requirements of the stakeholders, but mostly refers to areas aimed at creating a better corporate image of the company. However, this is not the case for other business sectors, as reflected in a study on the use of Twitter by a group of NGOs (Lovejoy and Saxton, 2012). Their results show that NGOs do in fact use Twitter to engage in dialogue with their stakeholders or even to mobilise them. However, unlike the sample of companies analysed here, this type 
of organisation (NGO) carries out activities that involve greater aware of CSR issues and, hence, they collaborate with their stakeholders.

Therefore, the company's objective in terms of CSR communication should be to know the demands of its stakeholders, and not just to disseminate information that improves its corporate image. Likewise, the person or persons in charge of managing the official profiles of organisations in their online social networks must be trained in the principles of CSR (Cortado and Chalmeta, 2016). Furthermore, as it is a communication platform within any individual's reach, those with important positions within these organisations, those with responsibility in the decision-making that creates business strategy and a sense of culture should also be involved in them. In some of the case studies, the participation of CEOs in the official profiles of the organisations was observed.

Although CSR cannot be conceived without taking into account the expectations of a company's stakeholders, the results shown in this work reveal an instrumental use of online social networks in the management of communication of CSR, given that there is no trace of the use of this communication tool in the companies' sustainability reporting. The possibility of analysing future contributions from stakeholders through this channel is not even under consideration.

In addition, taking into account the advantages offered by online networks for the implementation of a symmetrical two-way communication strategy, it should be expected that they will be considered in the implementation of corporate CSR management systems. Its gradual introduction into management systems would allow for greater standardisation of its use from a stakeholder involvement perspective in CSR, and not its use as a simple tool for distributing information on positive aspects of the company (more than half of the tweets are aimed only at society and customer stakeholders). This will increase the corporate reputation. Likewise, the differentiating feature of online social networks as a communication tool, the real-time interaction among all stakeholders, must be seen as an incentive to encourage the use of these networks by the organisations that work under CSR principles. Its importance lies in the fact that it promotes knowledge among ordinary users and helps to develop collective intelligence (Kolbitsch and Maurer, 2006).

In short, the presence on Twitter of all the companies studied, and the exponential growth in the broadcasting of tweets related to CSR reveal the importance of social networks for business management. This stimulates the development of actions that promote greater use of online social networks in CSR communication strategies, as they are presented as true communication tools with a high potential for exploitation with all stakeholders.

Therefore, from the information analysed throughout this work, some advice can be identified so as to create the most suitable environment for the adoption of a two-way collaborative communication strategy using online social networks that favours the participation of their stakeholders:

- The correct identification of all the stakeholders in the organisation. The stakeholder identification can be done with the help of previous studies, with support from managers or via a combination of both (Kumar et al., 2016).

- Publicising the existence of the business profile on Twitter to all stakeholders. 
- A constant follow-up of the posts made in the Twitter account for CSR communication with stakeholders. Organisations should not consider communicating CSR on Twitter as a one-time activity, but rather as an on-going process because there is a positive influence between the level of engagement of the stakeholders and the frequency that a given organisational account on Twitter tweeted about CSR (Araujo and Kollat, 2018). However, this positive influence can be broken if stakeholders detect that the company is trying to self-promoting (Kollat and Farache, 2017).

- It is also vital to construct appropriate messages in line with the context and content for effective results, because as Uzunoğlu et al. (2017) states it is also important to articulate the style and content, as well as the medium.

- An analysis of what issues interest stakeholders by analysing the issues they post on Twitter (Fredericks and Foth, 2013), because stakeholders' interests change depending on different issues such as the economic and social context, the company sector, etc. (Farache et al., 2018).

- An interactive use of online social networks that empowers stakeholders as members of the company who are aware that they can influence the performance of an organisation.

- The use of Twitter as a one-way communication strategy only for issues relevant to CSR (publication of reports, significant new investments within the organisation, changes in corporate governance within the company, etc.), in order to avoid watering down what is really important due to the excess of information.

- The inclusion of online social networks as communication tools in the guides for implementing CSR management systems, because online social networks can facilitate the way organisations interact with stakeholders directly. It is necessary to think strategically and timelessly about how managing social media in organisations for stakeholders engagement (Esfahani and Johnson, 2018).

- CSR training is needed for people in charge of managing online social network profiles in companies. They have to be actively involved in the development of CSR policies and skilled in the management of relationships with stakeholders (Cortado and Chalmeta, 2016).

- To enhance the active participation of senior members of the company in the online CSR communication strategy, making that they perceive the strategic possibilities that it offers to improve the visibility and legitimacy growth in the long run of the company, because there is an inverse relationship between company' CSR disclosure on Twitter and the tenure and age of the senior members of the company (Suárez-Rico et al., 2018).

\section{Conclusions}

The results of this work reveal the need to promote the advantages of the collaborative use of online social networks to improve CSR management. Social networks allow companies to reinforce an image that depicts honesty and transparency, as they represent 
a means by which their users' opinion cannot be monitored, nor can they hide information or distort it in order to enhance their reputation. This means that companies with a good communication strategy on social networks can consolidate their favourable corporate reputation over time and experience the advantages of truly integrating CSR principles into their management.

The use of Twitter as a communication tool is now being consolidated, as almost all the leading companies in their sector in Europe have an official profile. Likewise, the potential of Twitter is being reinforced as a medium that favours the promotion of CSR policies, through the data that confirms that more and more aspects related to it are being posted on this channel. However, there is still no real interest on the part of companies in terms of adopting a communication strategy that favours genuine dialogue with their stakeholders, given that the type of communication strategy adopted by these organisations in view of the content of the tweets posted is one-way. This conclusion is reinforced by the absence of a mention of Twitter as a CSR communication tool in the sustainability reports posted by the sample of companies analysed. This shows a lack of interest of these companies to meet the demands of their stakeholders in this way. In fact, they are using twitter as a tool for self-promoting instead of a tool for stakeholders engagement.

The conclusions that have been reached present some limitations that could be improved for future studies: Only one communication channel (Twitter) has been analysed. Considering the great diversity of interest groups and their different needs, it would be necessary to study other communication tools offered by Web 2.0 to ensure that all of them are included, as each channel would be better suited to a particular interest group (Charalabidis et al., 2014). Another limitation is that the official company accounts do not include tweets directed by other profiles. These messages can only be identified if the company issues a response or a retweet. Finally, another important limitation is that we use data (tweets) until June 2016. Therefore, complementary research should be done with current data to check if nowadays companies are founding an effective way to strategically manage social media and engage with various stakeholders using a two-way communication model, as there are no studies that prove it, and as a result there is a need to investigate this issue in depth (Esfahani and Johnson, 2018). The tweet content analysis could be useful to find examples of success cases that could be used as reference models to develop guidelines for organisations to engage with stakeholders and strategically managing CSR on social media. However, a limitation for researchers in twitter longitudinal analysis will be the cost to access the tweets database because the company wants to monetise them.

In future studies, the role of the stakeholder could be adopted by a researcher to analyse the type of strategy used by the company to respond to the demands of one of its stakeholders, as well as to show whether or not the online social network favours interaction. Finally, there may be other company profiles created for the posting of specific CSR issues. For example, in the case of BASF, a specific profile has been identified for issues related to the company's environmental impact (@BASF_SustyNA). For this reason, a more detailed search and identification of all official company profiles addressing different aspects of CSR is proposed for future research. 


\section{References}

Angeles, M. and Capriotti, M. (2009) 'Communicating CSR, citizenship and sustainability on the web', Journal of Communication Management, Vol. 13, pp.157-175.

Araujo, T. and Kollat, J. (2018) 'Communicating effectively about CSR on Twitter: the power of engaging strategies and storytelling elements', Internet Research, Vol. 28, No. 2, pp.419-431.

Baccarella, C.V., Wagner, T.F., Kietzmann, J.H. and McCarthy, I.P. (2018) 'Social media? It's serious! Understanding the dark side of social media', European Management Journal, Vol. 36, No. 4, pp.431-438.

Baksh-Mohammed, S., Callison, C. and Choi, M-H. (2012) 'Positive influence of organizational charitable involvement on perceptions of credibility and purchase intention', Public Relations Review, Vol. 38, No. 3, pp.498-500.

Casadesús, M., Heras, I. and Merino, J. (2005) Calidad Práctica. Una Guía Para no Perderse en el Mundo de la Calidad, Prentice Hall, Madrid.

Chae, B.K. and Park, E.O. (2018) 'Corporate social responsibility (CSR): a survey of topics and trends using Twitter data and topic modeling', Sustainability, Vol. 10, p.2231.

Chalmeta, R. and Viinikka, H. (2017) 'Corporate philanthropy communication on donor websites', Journal of Information, Communication and Ethics in Society, Vol. 15, No. 1, pp.53-73.

Charalabidis, Y., Loukis, E. and Androutsopoulou, A. (2014) 'Fostering social innovation through multiple social media combinations', Information Systems Management, Vol. 3, No. 13, pp.225-239.

Chaudhri, V. and Wang, J. (2007) 'Communicating corporate social responsibility on the internet. A case study of the top 100 information technology companies in India', Management Communication Quarterly, Vol. 21, pp.232-247.

Colleoni, E. (2013) 'CSR communication strategies for organizational legitimacy in social media', Corporate Communications: An International Journal, Vol. 18, No. 2, pp.228-248, https://doi.org/10.1108/13563281311319508.

Commission of the European Communities (2001) Brussels COM (2001), p.366.

Cortado, F-J. and Chalmeta, R. (2016) 'Use of social networks as a CSR communication tool', Cogent Business \& Management, Vol. 3, No. 1, p.e1187783, https://doi.org/10.1080/ 23311975.2016 .1187783$.

Cortado, F-J. and Chalmeta, R. (2016) 'Use of social networks as a CSR communication tool', Cogent Business \& Management, Vol. 3, No. 1, p.1187783.

Cunningham, R., Cvitanovic, C., Measham, T.G., Jacobs, B.C., Dowd, A. and Harman, B. (2015) 'Engaging communities in climate adaptation: the potential of social networks', Climate Policy, Vol. 16, No. 7, pp.894-908.

Escrig Tena, A.B. (UJI) Curso 2015/2016. 'Bloque temático del módulo Gestión de la RSC: Sistema de gestión de la Excelencia', Máster interuniversitario en Sostenibilidad y RSC (UNED-UJI)

Esfahani, L.M. and Johnson, L.W. (2018) 'Stakeholders' engagement and strategic management of social media', Journal of International Business Research and Marketing, Vol. 3, No. 6, pp.47-56.

Etter, M. (2013) 'Reasons for low levels of interactivity (non-) interactive CSR communication in Twitter', Public Relations Review, Vol. 39, pp.606-608.

Etter, M. (2014) 'Broadcasting, reacting, engaging-three strategies for CSR communication in Twitter', Journal of Communication Management, Vol. 18, No. 4, pp.322-342.

Ettinger, A., Grabner-Kräuter, S. and Terlutter, R. (2018) 'Online CSR communication in the hotel industry: evidence from small hotels', International Journal of Hospitality Management, Vol. 68, pp.94-104.

European Commission (2013) 'How companies influence our society: citizen's view' [online] http://ec.europa.eu/public_opinion/flash/fl_363_en.pdf. 
Farache, F., Tetchner, I. and Kollat, J. (2018) 'CSR communications on Twitter: an exploration into stakeholder reactions', in Grigore, G., Stancu, A. and McQueen, D. (Eds.): Corporate Responsibility and Digital Communities, Palgrave Studies in Governance, Leadership and Responsibility. Palgrave Macmillan, Cham.

Figge, F., Hahn, T., Schaltegger, S. and Wagner, M. (2001) 'The sustainability balanced scorecard - a tool for value-oriented sustainability management in strategy focused organisations', Conference Proceedings of the 2001 Eco-Management and Auditing Conference, ERP Environment, Shipley, pp.83-90.

Fredericks, J. and Foth, M. (2013) 'Augmenting public participation: enhancing planning outcomes through the use of social media and web 2.0', Australian Planner, Vol. 50, No. 3, pp.244-256.

Freeman, E. (1984) Strategic Management, A Stakeholder Approach, Pitman, London.

Freeman, R.E., Harrison, J.S., Wicks, A.C., Parmar, B.L. and De Colle, S. (2010) Stakeholder Theory. The State of the Art, Cambridge University Press.

Friedman, M. (1970) 'The social responsibility of business is to increase its profits', New York Times Magazine, Vols. 32,/33, pp.122-126.

Gómez, L. (2013) 'Me gusta o te sigo: análisis de la comunicación de prácticas de responsabilidad social corporativa a través de los medio sociales', Correspondencias y Análisis, Vol. 3, pp.89-109.

Gomez, L.M. and Chalmeta, R. (2011) 'Corporate responsibility in U.S. corporate websites: a pilot study', Public Relations Review, Vol. 37, pp.93-95.

GRI (2019) 'About sustainability reporting' [online] https://www.globalreporting.org/information/sustainability-reporting/Pages/default.aspx.

Ihlen, O., Bartlett, J.L. and May, S. (2011) Corporate Social Responsibility and Communication. The Handbook of Communication and Corporate Social Responsibility, pp.3-22, Wiley-Blackwell, Oxford.

Illia, L., Zyglidopoulos, S. and Romenti, S. (2015) 'Creating effective dialogue about corporate' social responsibility', MIT Sloan Management Review, Vol. 57, No. 1, pp.20-22.

Innovate Global Indices (2016) Eurostoxx 50 [online] https://www.stoxx.com/indexdetails? symbol=SX5E.

Kakabadse, N., Rozuel, C. and Lee-Davis, L. (2005) 'Corporate social responsibility and stakeholder approach: a conceptual review', Int. J. Business Governance and Ethics, Vol. 1, No. 4.

Kolbitsch, J. and Maurer, H.. (2006) 'Transformation of the web: how emerging communities shape the information we consume', Journal of Universal Computer Science, Vol. 12, No. 2, pp.187-213.

Kollat, J. and Farache, F. (2017) 'Achieving consumer trust on Twitter via CSR communication', Journal of Consumer Marketing, Vol. 34, No. 6, pp.505-514, https://doi.org/10.1108/JCM-032017-2127.

Kumar, V., Rahman, Z. and Kazmi, A. (2016) 'Stakeholder identification and classification: a sustainability marketing perspective', Management Research Review, Vol. 39 No. 1, pp.35-61, https://doi.org/10.1108/MRR-09-2013-0224.

Lovejoy, K. and Saxton, G.D. (2012) 'Information, community, and action: how nonprofit organizations use social media', Journal of Computed-Mediated Communication, Vol. 17, 2012, pp.337-353.

Lovejoy, K., Watters, R. and Saxton, G.D. (2012) 'Engaging stakeholders through Twitter: how nonprofit organizations are getting more out of 140 characters or less', Public Relations Review.

Maignan, I. (2001) 'Consumers' perceptions of corporate social responsibilities: a cross-cultural comparison', Journal of Business Ethics, Vol. 30, No. 1, pp.57-72.

McMillan, S. (2006) 'Exploring models of interactivity from multiple research traditions: users, documents, and systems', The Handbook of New Media, pp.205-229. 
Morsing, M. and Schultz, M. (2006) 'Corporate social responsibility communication: stakeholder information, response and involvement strategies', Business Ethics: A European Review, Vol. 15, No. 4.

Ruf, B.M., Muralidhar, K., Brown, R.M., Janney, J.J. and Paul, K. (2001) 'An empirical investigation of the relationship between change in corporate social performance and financial performance: a stakeholder theory perspective', Journal of Business Ethics, Vol. 32, No. 2, pp.143-156.

Smith, N.C. (2003) 'Corporate social responsibility: whether or how?', California Management Review, Vol. 45, No. 4, pp.52-76.

Suárez-Rico, Y.M., Gómez-Villegas, M. and García-Benau, M.A. (2018) 'Exploring Twitter for CSR disclosure: influence of CEO and firm characteristics in Latin American companies', Sustainability, Vol. 10, p.2617.

Szumniak-Samolej, J. (2019) 'Social media for corporate social responsibility strategy creation and communication in Poland: strategies, opportunities and challenges', in Corporate Social Responsibility in Poland, pp.273-286, Springer, Cham.

Truño, J. (2008) 'La reputación social corporativa: gestión empresarial de un activo intangible', Revista de Contabilidad y Dirección, No. 7, pp.163-184.

Twitter (2016) http://www.statista.com/statistics/282087/number-of-monthly-active-twitter-users/.

Uzunoğlu, E., Türkel, S. and Yaman Akyar, B. (2017) 'Engaging consumers through corporate social responsibility messages on social media: an experimental study', Public Relations Review, Vol. 43, No. 5, pp.989-997.

Visser, W. and Tolhurst, N. (2010) The World Guide to CSR. A Country-to-Country Analysis of Corporate Sustainability and Responsibility, Greenleaf Publishing, Sheffield.

Vollero, A., Palazzo, M., Siano, A. and Elving, W.J.L. (2016) 'Avoiding the greenwashing trap: between CSR communication and stakeholder engagement', International Journal of Innovation and Sustainable Development, Vol. 10, No. 2, pp.120-140.

Waters, R. and Williams, J. (2011) 'Squawking, tweeting, cooing, and hooting: analyzing the communication patterns of government agencies on Twitter', Journal of Public Affairs, Vol. 11, No. 4, pp.353-363.

Weiner, D. (2006) 'Crisis communications: managing corporate reputation in the court of public opinion', Ivey Business Journal.

Whelan, G., Moon, J. and Grant, B. (2013) 'Corporations and citizenship arenas in the age of social media', Journal of Business Ethics, Vol. 118, No. 4, pp.777-790.

Yin, J., Feng, J. and Wang, Y. (2015) 'social media and multinational corporations' corporate social responsibility in China: the case of ConocoPhillips oil spill', IEEE Transactions on Professional Communication, Vol. 58, No. 2, pp.135-153. 


\section{Appendix 1}

Total tweets per year and total CSR tweets per year of all the companies in the EuroStock50

\begin{tabular}{|c|c|c|c|c|c|c|c|}
\hline COMPANY & 2011 & 2012 & 2013 & 2014 & 2015 & $\begin{array}{l}2016 \text { (Until } \\
\text { June 2016) }\end{array}$ & TOTAL \\
\hline ABINBEVNEWS & - & 29 & 133 & 68 & 295 & 71 & 596 \\
\hline AIRBUSGROUP & - & - & - & 1.468 & 1.243 & 502 & 3.213 \\
\hline $\begin{array}{c}\text { AIRLIQUIDEGROU } \\
p\end{array}$ & - & - & 695 & 1.025 & 911 & 605 & 3.236 \\
\hline ALLIANZ SE & 238 & 436 & 369 & 344 & 474 & 596 & 2.457 \\
\hline ASMLCOMPANY & 354 & 256 & 276 & 193 & 381 & 283 & 1.743 \\
\hline AXA & - & - & - & 275 & 1.492 & 1.442 & 3.209 \\
\hline $\begin{array}{c}\text { BANCO } \\
\text { SANTANDER }\end{array}$ & - & 1.287 & 501 & 939 & 321 & 158 & 3.206 \\
\hline BASF & - & - & 116 & 743 & 1.456 & 903 & 3.218 \\
\hline BAYER & - & - & - & 677 & 1.541 & 1.002 & 3.220 \\
\hline BBVA & - & - & - & 134 & 119 & 3.248 & 3.501 \\
\hline BMWGROUP & 273 & 632 & 762 & 619 & 541 & 422 & 3.249 \\
\hline BNP PARIBAS & - & - & - & 1.102 & 1.240 & 889 & 3.231 \\
\hline $\begin{array}{c}\text { CARREFOURGRO } \\
\text { UP }\end{array}$ & - & . & - & 116 & 823 & 418 & 1.357 \\
\hline \begin{tabular}{|l} 
DAIMLER \\
\end{tabular} & 261 & 202 & 179 & 412 & 305 & 172 & 1.531 \\
\hline DANONE & - & 553 & 452 & 430 & 465 & 400 & 2.300 \\
\hline DEUTSCHE BANK & - & . & . & 105 & 1.773 & 1.366 & 3.244 \\
\hline DEUTSCHE POST & & & is no twitt & fficial prof & & & \\
\hline $\begin{array}{l}\text { DEUTSCHE } \\
\text { TELEKOM }\end{array}$ & - & - & . & 99 & 559 & 735 & 1.393 \\
\hline ENELGROUP & - & 395 & 554 & 436 & 761 & 848 & 2.994 \\
\hline ENGIEGROUP & - & - & - & & 1.367 & 1.832 & 3.199 \\
\hline ENI & - & 7 & 580 & 799 & 917 & 940 & 3.243 \\
\hline EON_SE_EN & - & - & - & 133 & 743 & 939 & 1.815 \\
\hline ESSILORUSA & - & - & - & 1.017 & 2.090 & 140 & 3.247 \\
\hline FRESENIUS SE & - & - & - & - & - & 21 & 21 \\
\hline GENERALI ASS & - & - & 63 & 870 & 798 & 670 & 2.401 \\
\hline IBERDROLA & - & - & - & - & 1.299 & 1.899 & 3.198 \\
\hline INDITEXCAREERS & - & 13 & 391 & 273 & 806 & 517 & 2.000 \\
\hline ING GROUP CVA & 113 & 129 & 328 & 461 & 498 & 484 & 2.013 \\
\hline $\begin{array}{c}\text { INTESA } \\
\text { SANPAOLO }\end{array}$ & - & . & - & - & 1.304 & 1.922 & 3.226 \\
\hline L'OREAL & - & - & - & - & 1.051 & 2.155 & 3.206 \\
\hline LVMH & - & - & - & - & 777 & 2.441 & 3.218 \\
\hline $\begin{array}{l}\text { MUNICH RE (O } \\
\text { MUENCH.RUECK) }\end{array}$ & - & - & - & - & 1.627 & 1.606 & 3.233 \\
\hline NOKIA & - & - & - & 2.128 & 372 & 740 & 3.240 \\
\hline ORANGE & - & - & - & - & & 2.912 & 2.912 \\
\hline PHILIPS KON & - & - & - & & 584 & 2.659 & 3.243 \\
\hline SAFRAN & - & - & - & 355 & 1.713 & 1.131 & 3.199 \\
\hline SAINT GOBAIN & - & - & - & 385 & 1.695 & 1.138 & 3.218 \\
\hline SANOFI & 39 & 40 & 150 & 441 & 1.257 & 901 & 2.828 \\
\hline SAP & - & - & - & 33 & 1.559 & 1.755 & 3.347 \\
\hline SCHNEIDERELEC & - & . & 153 & 1.147 & 1.145 & 777 & 3.222 \\
\hline SIEMENS & - & - & - & 675 & 1.685 & 858 & 3.218 \\
\hline $\begin{array}{c}\text { SOCIETE } \\
\text { GENERALE }\end{array}$ & 71 & 32 & 94 & 58 & 343 & 298 & 896 \\
\hline TELEFÓNICA & - & - & - & & & 3.205 & 3.205 \\
\hline TOTAL & 336 & 579 & 354 & 229 & 1.489 & 253 & 3.240 \\
\hline $\begin{array}{l}\text { UNIBAIL- } \\
\text { RODAMCO }\end{array}$ & \multicolumn{6}{|c|}{ There is no twitter official profile } & - \\
\hline Unicredit & - & - & - & 22 & 1.684 & 1.512 & 3.218 \\
\hline UNILEVER & & & 260 & 1.556 & 928 & 501 & 3.245 \\
\hline Vinci & 37 & 40 & 57 & 73 & 392 & 206 & 805 \\
\hline Vivendi & - & - & - & 429 & 1.603 & 1.203 & 3.235 \\
\hline VOLKSWAGEN & - & - & - & - & 246 & 376 & 622 \\
\hline TOTAL TWEETS & 1.722 & 4.630 & 6.467 & 20.269 & 44.672 & 50.051 & 127.811 \\
\hline $\begin{array}{l}\text { TOTAL CSR } \\
\text { TWEETS }\end{array}$ & 25 & 60 & 135 & 321 & 1.596 & 873 & 3.010 \\
\hline
\end{tabular}




\section{Appendix 2}

CSR tweets of one of the companies (see online version for colours)

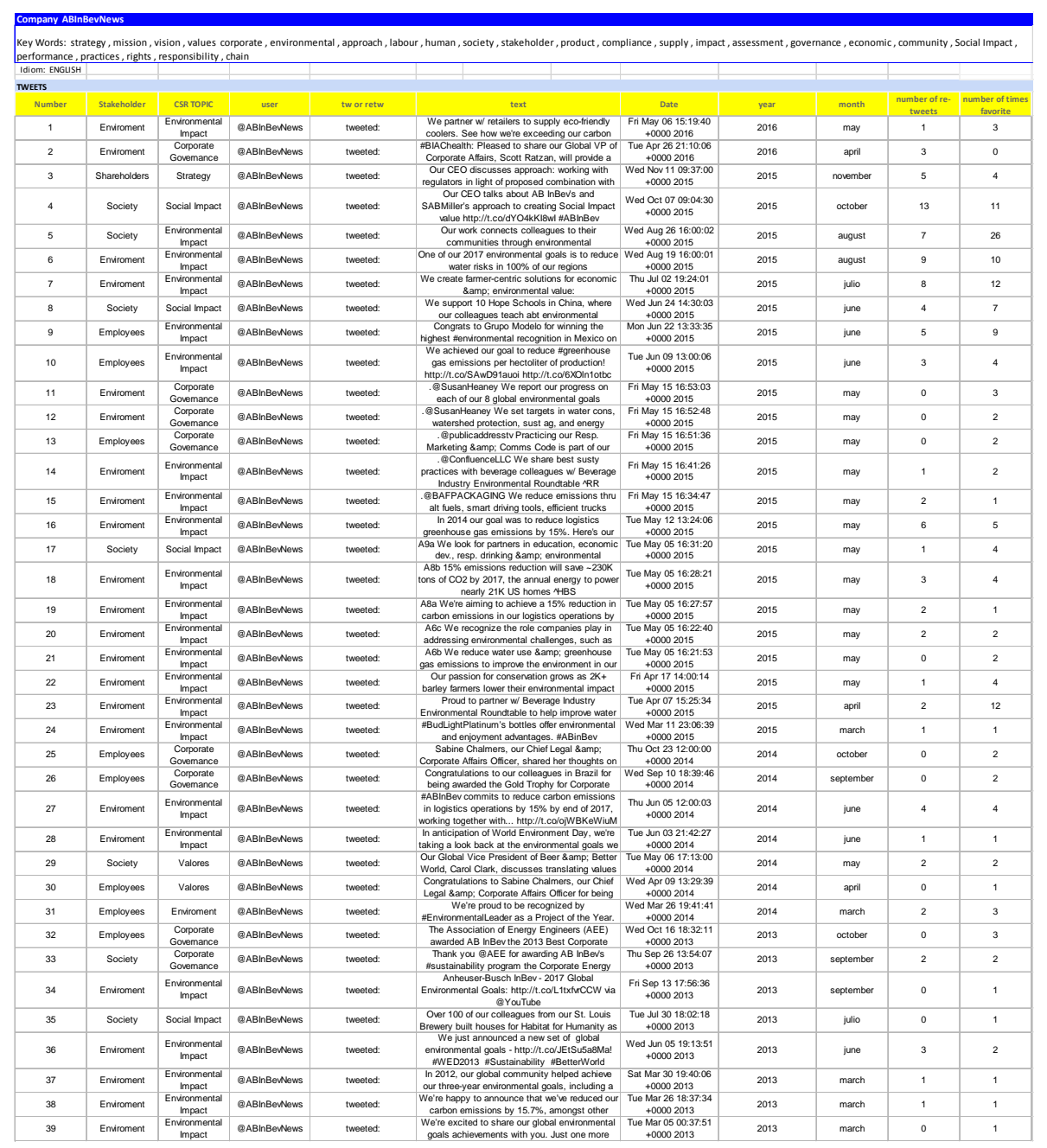

